\title{
Facial reconstruction: Soft tissue thickness values for South African black females
}

\author{
D. Cavanagh, M. Steyn* \\ Forensic Anthropology Research Centre, Department of Anatomy, University of Pretoria, P.O. Box 2034, Pretoria 0001, South Africa
}

\section{A R T I C L E I N F O}

Article history:

Received 13 December 2010

Accepted 3 January 2011

Available online $\mathrm{xxx}$

\section{Keywords:}

Forensic facial reconstruction

Personal identification

CT scan measurements

Soft tissue thickness

Population-specificity

Forensic Anthropology Population Data

\begin{abstract}
A B S T R A C T
In forensic science, investigators frequently have to deal with unidentified skeletonised remains. When conventional methods of identification are unsuccessful, forensic facial reconstruction (FFR) may be used, often as a last resort, to assist the process. FFR relies on the relationships between the facial features, subcutaneous soft tissues and underlying bony structure of the skull. The aim of this study was to develop soft tissue thickness (STT) values for South African black females for application to FFR, to compare these values to existing literature or databases and to add these values to existing population data. Computerised tomography scanning was used to determine average population-specific STT values at 28 facial landmarks of 154 black females. Descriptive statistics are provided for these STT values, which were also compared to those reported in three other comparable databases. Many of these STT values are significantly different from those reported for comparable groups, suggesting that individuals from different geographical areas have unique facial features thus requiring population-specific STT values. Repeatability tests indicated that most measurements could be recorded with a high degree of reliability.
\end{abstract}

(c) 2011 Elsevier Ireland Ltd. All rights reserved.

\section{Introduction}

Forensic facial reconstruction (FFR) is an attempt to reproduce a likeness of the facial features of an individual, based on characteristics of the skull, for the purpose of individual identification [1,2]. FFR is often conducted by a three-dimensional building up of the face, on a skull or a cast thereof, with artistic clay. For this purpose standard soft tissue thickness (STT) values and other anatomy-based rules are used [3-6]. Producing a face from the skull relies on the relationship between the soft tissues covering the skull and the underlying bony features. STT values are commonly used to determine the amount or the depth of the tissues that falls on certain predetermined landmarks of the skull $[5,7,8]$. This aids in the reconstruction of the face by giving a limit to work from when developing the initial face shape in the early stages of the reconstruction procedure. However, one of the problems associated with FFR is the reliance on the use of these average facial STTs [9], as well as the difficulty of estimating these values. Facial recognition is already extremely difficult, and is also further complicated by the variation exhibited by STT and facial features [10]. Many studies are ongoing to add to the database of STTs for specific age, sex and population groups, but there is still a lack of studies to establish whether the variation between sexes

\footnotetext{
* Corresponding author. Tel.: +27 12 4203256, fax: +27 123192240 .

E-mail address: maryna.steyn@up.ac.za (M. Steyn).
}

and ages within and between population groups may or may not be great enough to influence an identification or lack thereof [11].

Thus far, only two studies have been conducted on South African population groups. Aulsebrook et al. [12] developed STT standards for black male Zulus from KwaZulu-Natal, whereas Phillips and Smuts [1] did the same for a mixed origin population from the Cape Province areas. The Aulsebrook et al. study made use of radiographs and ultrasound of 55 males, while the Phillips and Smuts study used CT scans of 32 individuals. No standards exist for STT for the reconstruction of South African black female faces and, currently, STT values used come from data from American populations [3] (Capt. T.M. Briers, personal communication). Owing to this, the results are easily criticised and therefore the need to do a similar study on females of South African origin exists.

The aim of this study was therefore to develop STT values for South African black females, to add to the existing literature on STT values. These values will also be compared to existing databases in order to assess whether there are differences in tissue thicknesses that could potentially make a difference when it comes to actual facial reconstructions.

\section{Materials and methods}

CT scans obtained at the Steve Biko Hospital (previously known as the Pretoria Academic Hospital), Gauteng Province, South Africa, were used to obtain measurements of STT. As the landmarks can be located with precision and measurements can be taken with accuracy [13], it is convenient to utilise CT scans as a means of measuring facial STT [1]. The sample comprised 154 South African females between the ages of 18 and 35 years. All were patients that were subjected

0379-0738/\$ - see front matter (c) 2011 Elsevier Ireland Ltd. All rights reserved. doi:10.1016/j.forsciint.2011.01.009 


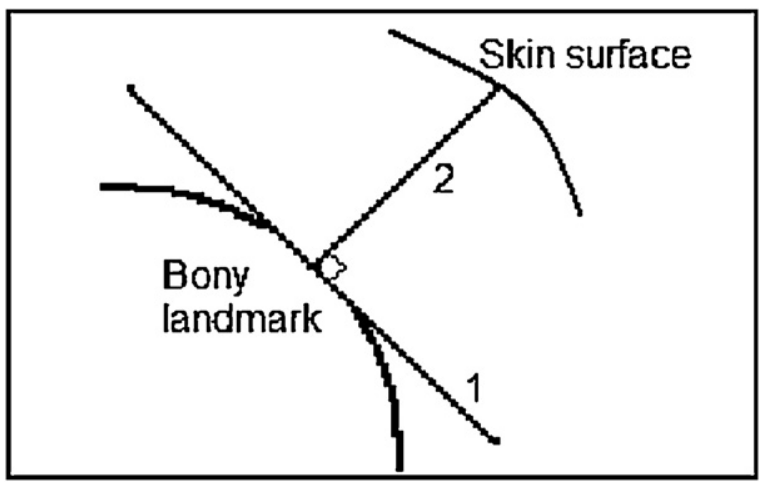

Fig. 1. Diagrammatic representation of establishing tissue thickness measurements.

to CT scans at the Steve Biko Hospital for reasons not related to this study. As was the case in the study by Sahni et al. [14], patients with head trauma, fractures, swellings, asymmetries, distortions, malformations or any abnormality that could influence the shape of the face or thickness of the subcutaneous tissues and musculature, were excluded from the sample. Unfortunately patient details such as weight and height could not be obtained, thus thin and obese subjects were also included in the sample.

Measurements were taken with the Image Tool of the CT scan program Centricity to the nearest tenth of a millimetre. The method of soft tissue measurement was similar to that described by Aulsebrook et al. [12], and was established as follows: a tangential line was drawn to the curve of the outer surface of the bony landmark (line 1 in Fig. 1). A line was drawn perpendicular to the tangent at the bony landmark, and extended outward to meet the facial profile (line 2 in Fig. 1). The length of the line from the bone to the junction with the skin surface was regarded as the equivalent STT at that landmark (Fig. 2).

The landmarks and measurements chosen for this study were previously used by researchers such as Phillips and Smuts [1], Wilkinson [5], Manhein et al. [11] and Aulsebrook et al. [12]. For this study, 28 biometric landmarks were identified and the tissue depth at each of these landmarks was measured on the CT scans. The locations correspond to the osteological landmarks. Midline landmarks were measured on a topogram view of the CT scans (Fig. 3a). The landmarks that fall on the three-quarter or lateral profiles were, by anthropometric convention, measured on the left side of the face on a horizontal slide (Fig. 3b). Some of these landmarks are used traditionally in FFR and were previously defined by Kollman and Buchly [15] and Suzuki [16]. Others were previously described by Aulsebrook et al. [12]. A few landmarks were newly identified by the authors as there are other areas on the face that no data are published on, but which could have an influence on FFR. For example, the South African black population group in general has prominent or protruding lips, but the existing STT data indicate thickness of lips over the alveoli of the teeth and not over the teeth itself, therefore extra measurements in these areas could be useful. Different researchers use different names for the same point, but for the purposes of this study various definitions for the landmarks were combined to produce one set of points for acquiring depth measurements on CT scans. The landmarks are listed and definitions summarised in Table 1, and are also indicated in Figs. 4 and 5.

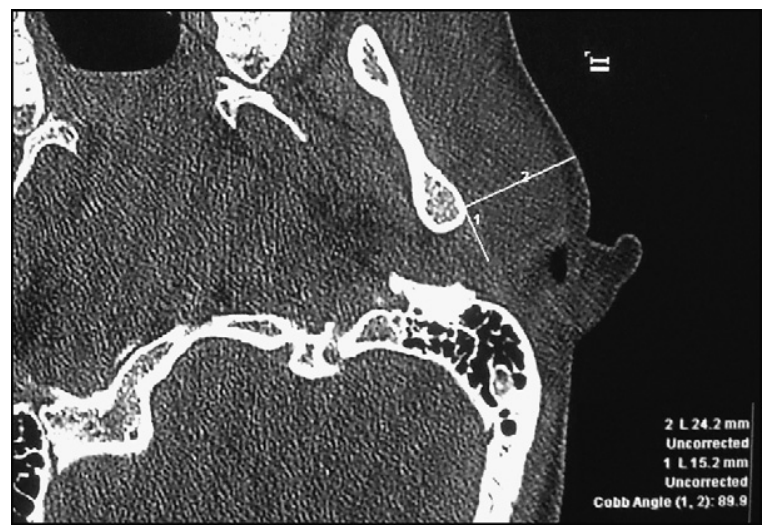

Fig. 2. Establishment of STT measurements. This is the measurement of landmark $U$ (area of the parotid). Line 1 is drawn tangential to the greatest curve of the bone and line 2 drawn perpendicular to line 1. At the bottom right corner a Cobb Angle is given between line 1 and line 2 , in this case $89.9^{\circ}$, to ensure the two lines are at an angle to each other as close to $90^{\circ}$ as possible.
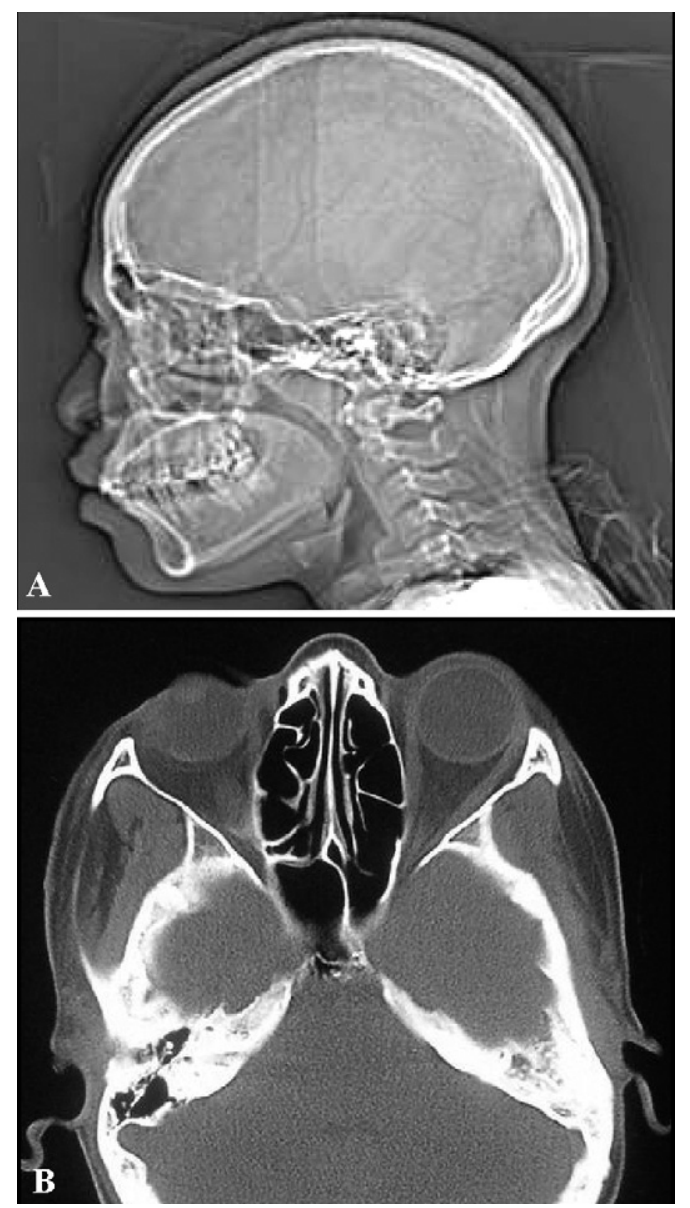

Fig. 3. (A) Topogram view of a CT scan. (B) A typical horizontal slice view from a CT scan.

In order to assess the reliability with which these measurements could be recorded, the measurements of 22 individuals were repeated by the investigator at a different time, and measurements of 29 individuals were repeated by an independent observer. The inter- and intra-observer repeatability between the original and second set of measurements was assessed by means of the intra-class correlation (ICC) coefficient, which reflects good repeatability when the value is close to one $[17,18]$.

The mean, range and standard deviation were calculated for each measurement and these means can in future be used for purposes of facial reconstruction. The mean of each value was compared to that of black females from the USA as reported by Manhein et al. [11], the revised tables from Rhine and Campbell [3] as well as a database for females of mixed ancestral origin, developed by Phillips and Smuts [1]. This was done by means of a Student's $t$-test, in order to assess whether significant differences exist in any of the values between the population groups.

\section{Results}

Basic descriptive statistics for the measurements are summarised in Table 2. Every measurement in this study could not be recorded from each of the CT scans due to a lack of control on the position of the CT scan of the patients, resulting in some of the scans only including the upper half of the face. On some scans there were also other objects such as respiratory tubes or bandages that influenced the clear visibility of the landmarks and skin surface. Therefore, every measurement has a different individual sample size $(n)$, with much smaller sample sizes for measurements on the mandible and lower maxillary region. The smallest sample size at any particular landmark was for $\mathrm{G}-$ mental tubercle $(n=17)$.

The landmarks that showed the smallest values include A (supra-glabella), N (frontal eminence) and $\mathrm{O}$ (fronto-temporale), which all fall on areas on the forehead, as well as D (end of nasals) and $\mathrm{E}$ (lateral nasal) on the nose. The largest values were measured 
Table 1

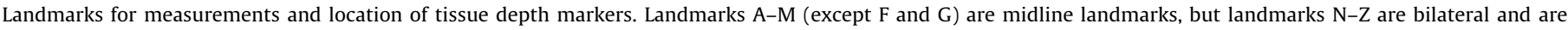
measured on the left side only.

\begin{tabular}{|c|c|}
\hline Landmark & Definition \\
\hline$A^{a}$ - supra-glabella & Above the glabella \\
\hline $\mathrm{B}^{\mathrm{a}}$ - glabella & Most prominent point between supra-orbital ridges in midsagittal plane \\
\hline $\mathrm{C}^{\mathrm{a}}-$ nasion & Midpoint of the suture between the frontal and the two nasal bones \\
\hline $\mathrm{D}^{\mathrm{a}}$ - end of nasals (rhinion) & Anterior tip of the nasal bones, on the internasal suture \\
\hline $\mathrm{E}^{\mathrm{c}}$ - lateral nasal & A point on the side of the bridge of the nose in line with the endocanthion, or inner corner of the eye \\
\hline $\mathrm{F}^{\mathrm{b}}$ - lateral supra-labiale (supra canine) & A point on the maximum bulge of the maxillary/upper canine eminence \\
\hline$G^{\mathrm{b}}$ - mental tubercle & Most prominent point on the lateral bulge of the chin mound \\
\hline $\mathrm{H}^{\mathrm{a}}$ - mid-philtrum (subspinale) & Midline of the maxilla, placed as high as possible before the curvature of the anterior nasal spine begins \\
\hline $\begin{array}{l}\mathrm{I}^{\mathrm{a}} \text { - mid upper lip margin } \\
\text { (supradentale or alveolare) }\end{array}$ & Centered between the maxillary (upper) central incisors at the level of the cementum-enamel junction \\
\hline $\mathrm{II}^{\mathrm{C}}$ - upper incisor & Halfway down the height of the enamel of the upper central incisors \\
\hline $\mathrm{J}^{\mathrm{a}}$ - mid lower lip margin (infradentale) & Centered between the mandibular (lower) central incisors at the level of the cementum-enamel junction \\
\hline $\mathrm{JJ}^{\mathrm{c}}$ - lower incisor & Halfway down the height of the enamel of the lower central incisors \\
\hline $\begin{array}{l}\mathrm{K}^{\mathrm{a}} \text { - supra-mentale (chin-lip fold or } \\
\text { mid labiomentale) }\end{array}$ & The deepest midline point of indentation on the mandible between the teeth and the chin protrusion \\
\hline $\begin{array}{l}\mathrm{L}^{\mathrm{a}}-\text { mental eminence (pogonion or } \\
\text { anterior symphyseal) }\end{array}$ & The most anterior projecting point in the midline on the chin \\
\hline $\mathrm{M}^{\mathrm{a}}$ - beneath chin (menton) & The lowest point on the mandible \\
\hline $\mathrm{N}^{\mathrm{a}}-$ frontal eminence & A point on the projections at both sides of the forehead \\
\hline $\mathrm{O}^{\mathrm{b}}$ - fronto-temporale & $\begin{array}{l}\text { The most medial point on the curve of the temporal ridge, on the frontal bones, } \\
\text { above the zygomaticofrontal suture }\end{array}$ \\
\hline$P^{a}$ - supra-orbital & Above the orbit, centered on the uppermost margin of the orbit \\
\hline$Q^{\mathrm{a}}$ - sub-orbital & Below the orbit, centered on the lowermost margin of the orbit \\
\hline $\mathrm{R}^{\mathrm{b}}$ - zygomaxillare & Lowest point on the suture between the zygomatic and maxillary bones \\
\hline$S^{\mathrm{b}}$ - lateral zygomatic arch (zygion) & A point on the maximum lateral outer curvature of the zygoma \\
\hline $\mathrm{T}^{\mathrm{a}}$ - supra-glenoid & Above, and slightly forward of the external auditory meatus \\
\hline $\mathrm{U}^{\mathrm{C}}-$ area of the parotid & A midline point between the external auditory meatus and point $\mathrm{V}$ (mid-masseteric) \\
\hline $\mathrm{V}^{\mathrm{b}}$ - mid-masseteric & $\begin{array}{l}\text { A point at the centre of an area bounded by the lower borders of the zygomatic arch and mandible, } \\
\text { anterior fibers of the masseter muscle and posterior border of the ascending ramus of the mandible }\end{array}$ \\
\hline $\mathrm{W}^{\mathrm{a}}$ - gonion & The most lateral point on the mandibular angle \\
\hline $\mathrm{X}^{\mathrm{a}}$ - supra $\mathrm{M}^{2}$ & Above the second maxillary molar \\
\hline $\mathrm{Y}^{\mathrm{a}}-\operatorname{sub} \mathrm{M}_{2}$ & Below the second mandibular molar \\
\hline$Z^{a}-$ occlusal line & $\begin{array}{l}\text { On anterior margin of the ramus of the mandible, in alignment with the line where } \\
\text { the teeth occlude or "bite" }\end{array}$ \\
\hline
\end{tabular}

\footnotetext{
a Landmarks defined by Rhine and Campbell [3] for measurements or location of tissue depth markers.

b Landmarks defined by Aulsebrook et al. [12] for measurements or location of tissue depth markers.

c Landmarks newly defined by the authors for measurements or location of tissue depth markers.
}

on the landmarks $\mathrm{R}$ (zygomaxillare), $\mathrm{U}$ (area of the parotid), $\mathrm{V}$ (mid-masseteric), $\mathrm{W}$ (gonion), $\mathrm{X}$ (supra $\mathrm{M}^{2}$ ), $\mathrm{Y}$ (sub $\mathrm{M}_{2}$ ) and $\mathrm{Z}$ (occlusal line). These are all landmarks that fall on the maxilla or mandible, therefore the areas around the mouth and cheeks. These are also the areas known to be the most variable in STT [8] and first to change along with changes in body weight and gain or loss of facial fat. This reflects the influence that different body builds can have on the results of the measurements.

The mode is included to indicate the most common value. It also gives an idea of the value when the effect of tissue thicknesses of very thin or obese people included in the sample is eliminated. The measurements with the greatest difference between the mean and mode (the difference indicated in brackets) are $\mathrm{W}$ (gonion; 2.07) and $\mathrm{Y}$ (sub $\mathrm{M}_{2}$; 3.07). No value is indicated for the mode at $\mathrm{G}$ (mental tubercle), since no value has been repeated that could be counted as a mode. At F (lateral supra-labiale), Q (sub-orbital), $\mathrm{R}$ (zygomaxillare), $\mathrm{U}$ (area of the parotid), $\mathrm{V}$ (mid-masseteric) and $\mathrm{Y}$ (sub $\mathrm{M}_{2}$ ), two or more values have occurred with the same maximum frequency, therefore no unique mode is indicated at these landmarks.

When comparing the STT values with results from other studies (Table 3), it should be taken into account that not all the measurements were included by other researchers. Also, Rhine and Campbell have not published the standard deviations in their paper, since they were concerned only with extracting data on means and ranges [3], thus the variability of the measurements were not available [8] and not all the statistical comparisons could be performed. The values from Rhine and Campbell in this study are as quoted from Taylor [19], but will still be referred to as the Rhine and Campbell [3] values. As can be seen from Table 3, many of these soft tissue thicknesses differ significantly from those reported by other authors.

The difference between the means is the difference in the values between the published results and the current study at each landmark. These range from 0.0 to $17.1 \mathrm{~mm}$. The landmarks that show the greatest difference between the means of the measurements in the various populations are those around the mouth (X supra $\mathrm{M}^{2}$ and $\mathrm{Y}-\operatorname{sub} \mathrm{M}_{2}$ ) and angle of the mandible ( $\mathrm{W}$ - gonion). It is expected that the greatest difference in appearance of reconstructions will be around these areas, but the influence of this will only be assessed when put to practical testing.

The ICC values, calculated for intra-observer repeatability, indicated that most of the measurements could be repeated with high accuracy. The measurements that showed the highest intraobserver repeatability were the lower incisor $(\mathrm{JJ}$; ICC $=0.904)$ and lateral zygomatic arch $(S$; ICC $=0.919)$ measurements. Measurements that did not correlate well between first and second readings were that of the glabella $(B)$, mid-philtrum $(H)$, mid lower lip margin $(\mathrm{J})$, frontal eminence $(\mathrm{N})$ and zygomaxillare $(\mathrm{R})$, indicating that these could not be re-measured by the original investigator with a high degree of reliability. These ICC values ranged between 0.425 and 0.553 .

The second observer was able to re-measure all the dimensions with precision. The highest ICC values were calculated for the suborbital ( $Q ; 0.930)$, lateral zygomatic arch ( $;$; 0.946), midmasseteric $(\mathrm{V} ; 0.924)$ and occlusal line $(\mathrm{Z} ; 0.922)$ measurements. 


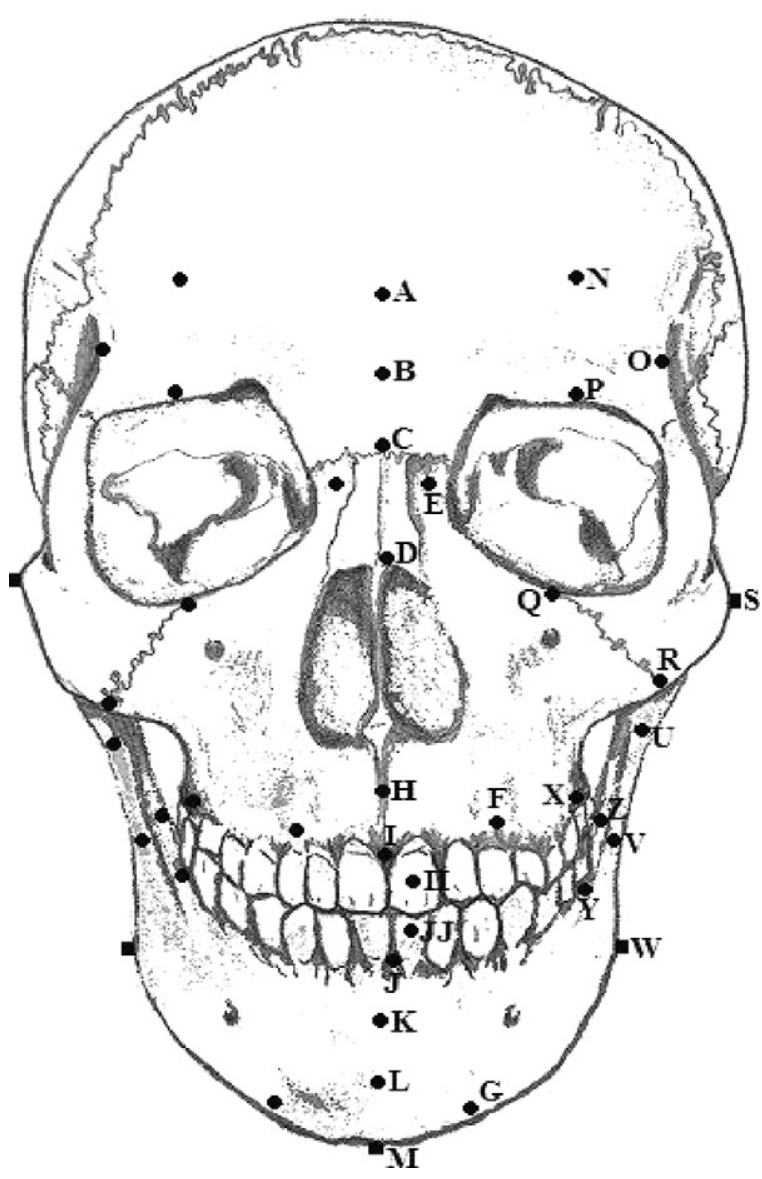

Fig. 4. Frontal view landmarks for measurements or location of tissue depth markers. The landmarks are described in Table 1.

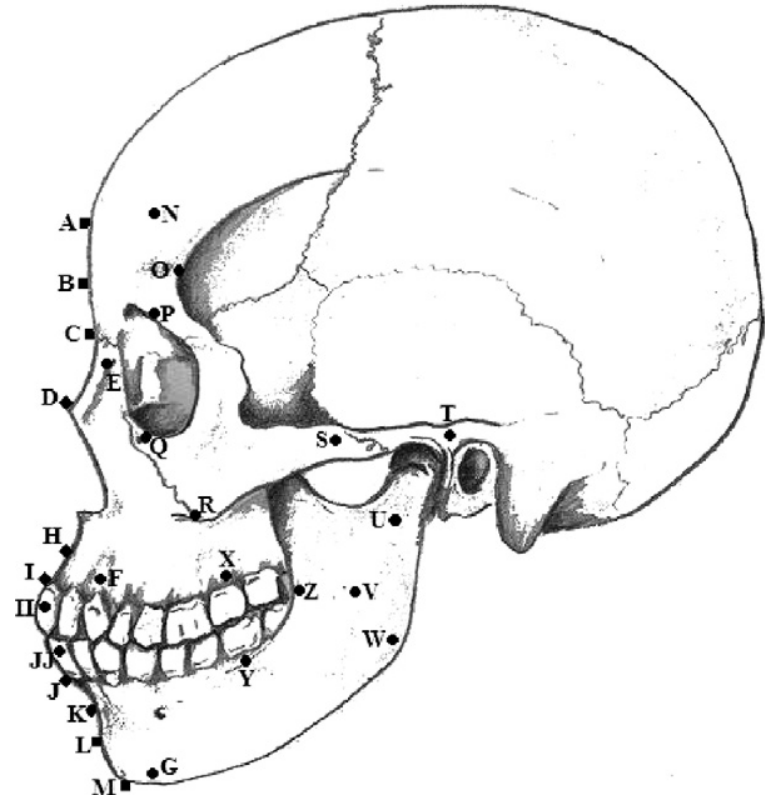

Fig. 5. Lateral view landmarks for measurements or location of tissue depth markers. The landmarks are described in Table 1.

With the inter-observer repeatability the measurements for the lateral supra-labiale $(\mathrm{F})$ and mid-philtrum $(\mathrm{H})$ landmarks appeared to be the most unreliable, but both these values were above 0.545 .

\section{Discussion}

The results presented here provide a set of average facial soft tissue depth measurements to contribute to a more accurate reproduction of a face on a skull. These are for specific application to the skull of black females, specifically of South African origin, as

Table 2

Basic descriptive statistics ( $n=$ sample size for each measurement; SD = standard deviation; $\min .=$ minimum; max. $=$ maximum).

\begin{tabular}{|c|c|c|c|c|c|c|}
\hline Measurement & $n$ & Mean (in mm) & SD & Mode (in mm) & Min. & Max. \\
\hline A - supra-glabella & 150 & 4.7 & 1.185 & 4.1 & 2.0 & 8.1 \\
\hline B - glabella & 152 & 6.3 & 1.287 & 5.1 & 3.1 & 10.5 \\
\hline$C$ - nasion & 141 & 6.0 & 1.552 & 7.1 & 2.2 & 12.0 \\
\hline D - end of nasals & 132 & 2.7 & 0.975 & 2.2 & 1.4 & 8.2 \\
\hline E - lateral nasal & 148 & 4.3 & 1.132 & 3.9 & 2.0 & 8.2 \\
\hline F - lateral supra-labiale & 59 & 10.2 & 1.672 & - & 7.2 & 14.5 \\
\hline G - mental tubercle & 17 & 12.6 & 2.713 & - & 7.1 & 17.4 \\
\hline $\mathrm{H}$ - mid-philtrum & 138 & 10.9 & 1.409 & 10.8 & 7.2 & 14.8 \\
\hline I - mid upper lip margin & 121 & 13.3 & 1.761 & 14.3 & 7.6 & 17.7 \\
\hline II - upper incisor & 118 & 10.3 & 1.958 & 10.0 & 5.1 & 18.0 \\
\hline $\mathrm{J}$ - mid lower lip margin & 95 & 14.7 & 1.912 & 16.1 & 9.4 & 21.5 \\
\hline $\mathrm{JJ}$ - lower incisor & 99 & 13.4 & 1.673 & 13.9 & 9.2 & 21.5 \\
\hline $\mathrm{K}$ - supra-mentale & 91 & 12.2 & 1.988 & 10.8 & 9.1 & 16.8 \\
\hline $\mathrm{L}$ - mental eminence & 64 & 10.6 & 1.910 & 10.0 & 6.1 & 17.1 \\
\hline M - beneath chin & 42 & 6.7 & 1.455 & 6.1 & 4.0 & 10.0 \\
\hline $\mathrm{N}$ - frontal eminence & 148 & 4.8 & 1.256 & 4.3 & 2.3 & 8.3 \\
\hline $\mathrm{O}$ - fronto-temporale & 148 & 4.6 & 1.348 & 4.6 & 2.3 & 9.1 \\
\hline P - supra-orbital & 148 & 6.8 & 1.371 & 6.5 & 4.0 & 9.9 \\
\hline Q - sub-orbital & 140 & 6.9 & 2.374 & - & 3.1 & 13.7 \\
\hline $\mathrm{R}$ - zygomaxillare & 83 & 18.7 & 3.427 & - & 7.1 & 26.0 \\
\hline S - lateral zygomatic arch & 151 & 8.4 & 2.767 & 9.0 & 3.4 & 19.9 \\
\hline $\mathrm{T}$ - supra-glenoid & 151 & 12.0 & 2.188 & 11.3 & 7.6 & 19.2 \\
\hline $\mathrm{U}$ - area of the parotid & 145 & 19.5 & 3.689 & - & 9.3 & 29.1 \\
\hline V - mid-masseteric & 128 & 22.4 & 3.708 & - & 12.1 & 34.9 \\
\hline W - gonion & 26 & 17.9 & 4.353 & 15.6 & 11.1 & 27.4 \\
\hline $\mathrm{X}$ - supra $\mathrm{M}^{2}$ & 72 & 30.1 & 4.431 & 29.3 & 20.1 & 37.8 \\
\hline $\mathrm{Y}-\operatorname{sub} \mathrm{M}_{2}$ & 25 & 21.7 & 4.254 & - & 13.4 & 28.7 \\
\hline Z - occlusal line & 44 & 21.6 & 3.930 & 22.2 & 14.3 & 31.4 \\
\hline
\end{tabular}


Table 3

Comparison of data from the current study (Current) with that of Manhein et

al. [11] (Man), Phillips and Smuts [1] (P\&S) and Rhine and Campbell [3] (R\&C).

\begin{tabular}{|c|c|c|c|c|c|c|}
\hline Landmark & Study & Sample size $(n)$ & Mean (SD) & $95 \% \mathrm{CI}$ & $\begin{array}{l}\text { Difference } \\
\text { between means }\end{array}$ & $\begin{array}{l}p \text {-Value } \\
\text { (vs. current) }\end{array}$ \\
\hline \multirow[t]{4}{*}{ A - supra-glabella } & Current & 150 & 4.68 (1.19) & $(4.488 ; 4.872)$ & - & - \\
\hline & Man & - & - & - & - & - \\
\hline & $\mathrm{P} \& \mathrm{~S}$ & 16 & $4.88(1.02)$ & $(4.336 ; 5.424)$ & 0.20 & 0.472 \\
\hline & $\mathrm{R} \& \mathrm{C}$ & 15 & $4.50(-)$ & - & 0.18 & 0.069 \\
\hline \multirow{4}{*}{ B - glabella } & Current & 152 & $6.28(1.29)$ & $(6.073 ; 6.487)$ & - & - \\
\hline & Man & 18 & $4.60(0.70)$ & $(4.252 ; 4.948)$ & 1.68 & $0.000^{* *}$ \\
\hline & $\mathrm{P} \& \mathrm{~S}$ & 16 & $5.64(1.42)$ & $(4.883 ; 6.397)$ & 0.64 & 0.101 \\
\hline & $\mathrm{R} \& \mathrm{C}$ & 15 & $6.00(-)$ & - & 0.28 & $0.008^{* *}$ \\
\hline \multirow[t]{4}{*}{$C$ - nasion } & Current & 141 & $6.00(1.55)$ & $(5.740 ; 6.260)$ & - & - \\
\hline & Man & 18 & $6.00(0.84)$ & $(5.582 ; 6.418)$ & 0.00 & 1.000 \\
\hline & $\mathrm{P} \& S$ & 16 & $4.68(2.35)$ & $(3.428 ; 5.932)$ & 1.32 & $0.043^{*}$ \\
\hline & $\mathrm{R} \& \mathrm{C}$ & 15 & $5.25(-)$ & - & 0.75 & $0.000^{* *}$ \\
\hline \multirow[t]{4}{*}{ D - end of nasals } & Current & 132 & $2.72(0.98)$ & $(2.542 ; 2.882)$ & - & - \\
\hline & Man & 18 & $1.70(0.46)$ & $(1.471 ; 1.929)$ & 1.01 & $0.000^{* *}$ \\
\hline & P\&S & 16 & $2.78(0.91)$ & $(2.295 ; 3.265)$ & 0.07 & 0.783 \\
\hline & $\mathrm{R} \& \mathrm{C}$ & 15 & $3.75(-)$ & - & 1.04 & $0.000^{* *}$ \\
\hline \multirow[t]{4}{*}{ E - lateral nasal } & Current & 148 & $4.26(1.13)$ & - & - & - \\
\hline & Man & - & - & - & - & - \\
\hline & P\&S & - & - & - & - & - \\
\hline & $\mathrm{R} \& \mathrm{C}$ & - & - & - & - & - \\
\hline \multirow[t]{4}{*}{ F - lateral supra-labiale } & Current & 59 & $10.19(1.67)$ & $(9.755 ; 10.625)$ & - & - \\
\hline & Man & 18 & $10.00(2.28)$ & $(8.866 ; 11.134)$ & 0.19 & 0.746 \\
\hline & $\mathrm{P} \& \mathrm{~S}$ & - & - & - & - & - \\
\hline & $\mathrm{R} \& \mathrm{C}$ & - & - & - & - & - \\
\hline \multirow[t]{4}{*}{ G - mental tubercle } & Current & 17 & $12.61(2.71)$ & $(11.227 ; 13.993)$ & - & - \\
\hline & Man & 18 & $12.60(2.85)$ & $(11.183 ; 14.017)$ & 0.01 & 0.992 \\
\hline & $\mathrm{P} \& \mathrm{~S}$ & - & - & - & - & - \\
\hline & $\mathrm{R} \& \mathrm{C}$ & - & - & - & - & - \\
\hline $\mathrm{H}$ - mid-philtrum & Current & 138 & $10.92(1.41)$ & $(10.683 ; 11.157)$ & - & - \\
\hline & Man & 18 & $9.20(1.82)$ & $(8.295 ; 10.105)$ & 1.72 & $0.001^{* *}$ \\
\hline & $\mathrm{P} \& \mathrm{~S}$ & 16 & $10.13(2.48)$ & $(8.809 ; 11.452)$ & 0.79 & 0.229 \\
\hline & $\mathrm{R} \& \mathrm{C}$ & 15 & $11.25(-)$ & - & 0.33 & $0.006^{* *}$ \\
\hline I - mid upper lip margin & Current & 121 & $13.30(1.76)$ & $(12.983 ; 13.617)$ & - & - \\
\hline & Man & - & - & - & - & - \\
\hline & $P \& S$ & - & - & - & - & - \\
\hline & $\mathrm{R} \& \mathrm{C}$ & 15 & $12.50(-)$ & - & 0.8 & $0.000^{* *}$ \\
\hline II - upper incisor & Current & 118 & $10.32(1.96)$ & $(9.963 ; 10.677)$ & - & - \\
\hline & Man & - & - & - & - & - \\
\hline & $P \& S$ & 16 & $13.63(3.7)$ & (11.658; 15.602) & 3.31 & $0.003^{* *}$ \\
\hline & $\mathrm{R} \& \mathrm{C}$ & - & - & - & - & - \\
\hline $\mathrm{J}$ - mid lower lip margin & Current & 95 & $14.65(1.91)$ & $(14.264 ; 15.043)$ & - & - \\
\hline & Man & - & - & - & - & - \\
\hline & $P \& S$ & - & - & - & - & - \\
\hline & $\mathrm{R} \& \mathrm{C}$ & 15 & $15.00(-)$ & - & 0.35 & 0.081 \\
\hline $\mathrm{JJ}$ - lower incisor & Current & 99 & $13.39(1.67)$ & $(13.059 ; 13.721)$ & - & - \\
\hline & Man & - & - & - & - & - \\
\hline & $P \& S$ & 16 & $12.45(2.31)$ & (11.219; 13.681) & 0.94 & 0.135 \\
\hline & $\mathrm{R} \& \mathrm{C}$ & - & - & - & - & - \\
\hline $\mathrm{K}$ - supra-mentale & Current & 91 & 12.21 (1.99) & $(11.796 ; 12.624)$ & - & - \\
\hline & Man & 18 & $11.80(2.20)$ & $(10.706 ; 12.894)$ & 0.41 & 0.471 \\
\hline & $\mathrm{P} \& \mathrm{~S}$ & 16 & $11.70(1.66)$ & $(10.815 ; 12.585)$ & 0.51 & 0.283 \\
\hline & $\mathrm{R} \& \mathrm{C}$ & 15 & $12.25(-)$ & - & 0.04 & 0.831 \\
\hline $\mathrm{L}$ - mental eminence & Current & 64 & $10.61(1.91)$ & $(10.133 ; 11.087)$ & - & - \\
\hline & Man & 18 & $10.80(2.68)$ & $(9.467 ; 12.133)$ & 0.19 & 0.781 \\
\hline & $\mathrm{P} \& \mathrm{~S}$ & 16 & $9.57(2.36)$ & $(8.312 ; 10.828)$ & 1.04 & 0.117 \\
\hline & $\mathrm{R} \& \mathrm{C}$ & 15 & $12.50(-)$ & - & 1.89 & $0.000^{* * *}$ \\
\hline M - beneath chin & Current & 42 & $6.72(1.46)$ & $(6.265 ; 7.175)$ & - & - \\
\hline & Man & 18 & $6.70(2.02)$ & $(5.695 ; 7.705)$ & 0.02 & 0.970 \\
\hline & $\mathrm{P} \& \mathrm{~S}$ & 16 & $6.47(1.57)$ & $(5.633 ; 7.307)$ & 0.25 & 0.585 \\
\hline & $\mathrm{R} \& \mathrm{C}$ & 15 & $8.00(-)$ & - & 1.28 & $0.000^{* *}$ \\
\hline $\mathrm{N}$ - frontal eminence & Current & 148 & $4.75(1.26)$ & $(4.545 ; 4.955)$ & - & - \\
\hline & Man & - & - & - & - & - \\
\hline & $P \& S$ & 16 & $4.78(1.74)$ & (3.853; 5.707) & 0.03 & 0.947 \\
\hline & $\mathrm{R} \& \mathrm{C}$ & 15 & $4.00(-)$ & - & 0.75 & $0.000^{* *}$ \\
\hline $\mathrm{O}$ - fronto-temporale & Current & 148 & $4.60(1.35)$ & - & - & - \\
\hline & Man & - & - & - & - & - \\
\hline & $P \& S$ & - & - & - & - & - \\
\hline & $\mathrm{R} \& \mathrm{C}$ & - & - & - & - & - \\
\hline P - supra-orbital & Current & 148 & $6.84(1.37)$ & $(6.617 ; 7.063)$ & - & - \\
\hline & Man & 18 & $6.10(0.83)$ & $(5.687 ; 6.513)$ & 0.74 & $0.003^{* *}$ \\
\hline & $P \& S$ & 16 & $5.79(1.89)$ & $(4.783 ; 6.797)$ & 1.05 & $0.045^{*}$ \\
\hline & $\mathrm{R} \& \mathrm{C}$ & 15 & $8.00(-)$ & - & 1.16 & $0.000^{* *}$ \\
\hline Q - sub-orbital & Current & 140 & $6.89(2.37)$ & $(6.494 ; 7.286)$ & - & - \\
\hline & Man & 18 & $6.20(1.17)$ & $(5.618 ; 6.782)$ & 0.69 & $0.050^{*}$ \\
\hline & $\mathrm{P} \& \mathrm{~S}$ & 16 & $6.42(3.83)$ & $(4.379 ; 8.461)$ & 0.47 & 0.637 \\
\hline & $\mathrm{R} \& \mathrm{C}$ & 15 & $8.25(-)$ & - & 1.36 & $0.000^{* *}$ \\
\hline
\end{tabular}

Please cite this article in press as: D. Cavanagh, M. Steyn, Facial reconstruction: Soft tissue thickness values for South African black females, Forensic Sci. Int. (2011), doi:10.1016/j.forsciint.2011.01.009 
Table 3 (Continued)

\begin{tabular}{|c|c|c|c|c|c|c|}
\hline Landmark & Study & Sample size $(n)$ & Mean (SD) & $95 \% \mathrm{CI}$ & $\begin{array}{l}\text { Difference } \\
\text { between means }\end{array}$ & $\begin{array}{l}p \text {-Value } \\
\text { (vs. current) }\end{array}$ \\
\hline \multirow[t]{4}{*}{ R - zygomaxillare } & Current & 83 & $18.67(3.43)$ & $(17.920 ; 19.417)$ & - & - \\
\hline & Man & - & - & - & - & - \\
\hline & P\&S & - & - & - & - & - \\
\hline & $\mathrm{R} \& \mathrm{C}$ & 15 & $16.75(-)$ & - & 1.92 & $0.000^{* *}$ \\
\hline \multirow[t]{4}{*}{ S - lateral zygomatic arch } & Current & 151 & $8.41(2.77)$ & $(7.965 ; 8.855)$ & - & - \\
\hline & Man & 18 & $6.40(2.25)$ & $(5.281 ; 7.519)$ & 2.01 & $0.002^{* *}$ \\
\hline & $\mathrm{P} \& S$ & 16 & $9.30(3.21)$ & $(7.590 ; 11.01)$ & 0.89 & 0.299 \\
\hline & $\mathrm{R} \& \mathrm{C}$ & 15 & $9.50(-)$ & - & 1.09 & $0.000^{* *}$ \\
\hline \multirow[t]{4}{*}{$\mathrm{T}$ - supra-glenoid } & Current & 151 & $12.01(2.19)$ & $(11.658 ; 12.362)$ & - & - \\
\hline & Man & 18 & $6.40(2.25)$ & $(5.281 ; 7.519)$ & 5.61 & $0.000^{* *}$ \\
\hline & $\mathrm{P} \& \mathrm{~S}$ & 16 & $8.44(3.84)$ & $(6.394 ; 10.486)$ & 3.57 & $0.002^{* *}$ \\
\hline & $\mathrm{R} \& \mathrm{C}$ & 15 & $11.50(-)$ & - & 0.51 & $0.005^{* *}$ \\
\hline \multirow[t]{4}{*}{$\mathrm{U}$ - area of the parotid } & Current & 145 & $19.51(3.69)$ & - & - & - \\
\hline & Man & - & - & - & - & - \\
\hline & $\mathrm{P} \& \mathrm{~S}$ & - & - & - & - & - \\
\hline & $\mathrm{R} \& \mathrm{C}$ & - & - & - & - & - \\
\hline \multirow[t]{4}{*}{$\mathrm{V}$ - mid-masseteric } & Current & 128 & $22.38(3.71)$ & - & - & - \\
\hline & Man & - & - & - & - & - \\
\hline & $\mathrm{P} \& S$ & - & - & - & - & - \\
\hline & $\mathrm{R} \& \mathrm{C}$ & - & - & - & - & - \\
\hline \multirow[t]{4}{*}{ W - gonion } & Current & 26 & $17.90(4.35)$ & $(16.143 ; 19.657)$ & - & - \\
\hline & Man & 18 & $18.00(4.23)$ & $(16.291 ; 19.709)$ & 0.10 & 0.941 \\
\hline & $\mathrm{P} \& \mathrm{~S}$ & 16 & $13.50(6.60)$ & $(9.983 ; 17.017)$ & 4.40 & $0.026^{*}$ \\
\hline & $\mathrm{R} \& \mathrm{C}$ & 15 & $13.50(-)$ & - & 4.40 & $0.000^{* *}$ \\
\hline \multirow[t]{4}{*}{$\mathrm{X}$ - supra $\mathrm{M}^{2}$} & Current & 72 & $30.11(4.43)$ & $(29.069 ; 31.151)$ & - & \\
\hline & Man & 18 & $26.60(4.36)$ & $(24.432 ; 28.768)$ & 3.51 & $0.005^{* *}$ \\
\hline & $\mathrm{P} \& S$ & 16 & $12.99(4.45)$ & $(10.619 ; 15.361)$ & 17.12 & $0.000^{* *}$ \\
\hline & $\mathrm{R} \& \mathrm{C}$ & 15 & $20.25(-)$ & - & 9.86 & $0.000^{* *}$ \\
\hline \multirow[t]{4}{*}{$\mathrm{Y}-\operatorname{sub} \mathrm{M}_{2}$} & Current & 25 & $21.67(4.25)$ & $(19.916 ; 23.424)$ & - & - \\
\hline & Man & 18 & 21.70 (3.99) & $(19.716 ; 23.684)$ & 0.03 & 0.981 \\
\hline & $\mathrm{P} \& \mathrm{~S}$ & 16 & $11.88(5.95)$ & $(8.709 ; 15.051)$ & 9.79 & $0.000^{* *}$ \\
\hline & $\mathrm{R} \& \mathrm{C}$ & 15 & $17.00(-)$ & - & 4.67 & $0.000^{* *}$ \\
\hline \multirow[t]{4}{*}{ Z - occlusal line } & Current & 44 & $21.60(3.93)$ & $(20.405 ; 22.795)$ & - & - \\
\hline & Man & - & - & - & - & - \\
\hline & $\mathrm{P} \& S$ & 16 & $21.26(8.37)$ & $(16.800 ; 25.720)$ & 0.34 & 0.878 \\
\hline & $\mathrm{R} \& \mathrm{C}$ & 15 & $19.25(-)$ & - & 2.35 & $0.0003^{* *}$ \\
\hline
\end{tabular}

${ }^{*} p \leq 0.05$.

$p \leq 0.01$.

a guide to the depth of the soft tissues overlying the skull. The wide ranges seen for some of the measurements reflect the influence that different body builds can have on the results of STT measurements and show how tissues in the face can change along with a change in body weight and gain or loss of facial fat. It also reflects inter-individual variation.

When compared to other databases (Table 3), STT values at many landmarks show significant differences. A total of nine landmarks are significantly different as compared to data from Manhein et al. [11] ( $p \leq 0.01)$, four with Phillips and Smuts [1] at $p \leq 0.01$ and three at $p \leq 0.05$, and 17 with Rhine and Campbell [3] $(p \leq 0.01)$. Some of these differences may possibly be attributed to difference in positioning [6] of the subjects on which the measurements were taken, in other words the upright position for ultrasound-based measurements [6,11], or supine for CT scans $[1,6]$ and cadaver-based measurements [3]. However, clear differences were observed indicating that population-specific values should be used for FFR. This is especially true for values around the mouth area (supra $\mathrm{M}^{2}$ and sub $\mathrm{M}_{2}$ ), which were found to differ most. The least differences were observed between values from the current study and South African (Cape) Coloured females [1] as could be expected due to possible genetic similarities between these groups.

The smaller or limited number of subjects used in past and existing studies has been questioned, and it can be asked whether the subjects are representative of a specific population group [8]. The small sample size may also contribute to the considerable variation that is seen in results [14]. In order to measure STT values that resemble that of a whole population, a substantial number of
CT scans is needed. The number of individuals measured per landmark in this study ranged between 17 and 152 which is a fairly large sample. Since this study was conducted in the northern part of the country, we can presume that it reflects the Gauteng area's population groups, but less well other population groups elsewhere in South Africa. Also, the ideal would have been to use CT scans of individuals of which the age, ancestry, exact health status and BMI were known. Unfortunately, recruiting volunteers to be scanned is an ethical problem due to unnecessary exposure to radiation, albeit small. Therefore, CT scans had to be used from patients already on file. The shortcoming of this is that the BMI of these individuals could not be obtained, therefore the CT scans could not be categorised according to BMI and this prevented the measurement of average STTs for different classes of body builds. The average STTs shown in this study is that of the whole range of possible body composition of the population group.

Data regarding age, sex and body build are generally limited, however it has been stated that sub-categorisation of soft tissue data is of little practical benefit, and it is suggested that the data should rather be assimilated to increase sample sizes to provide a more statistically powerful, yet simplified, data set [20,21].

Stephan and Simpson [21] stated that the population differences that do exist (even the differences within population groups) are likely overpowered by the differences caused between different measurement methods, meaning that linked to the limited tissue thickness data is the lack of a standard method for determining these tissue thickness values and approximating facial features [22]. Using different measurement methods, each with its own advantages, disadvantages and measuring errors, 
contributes to the variation that occur in STT data, since it affects the magnitude and accuracy of the obtained values, as well as the confidence with which the values can be regarded as accurate $[14,21]$. There is also no way to tell which method provides the best resemblance of the true STT of humans [21], but refinement of the methods, additional data and larger samples, including regional variations, as well as practical and identification tests on this data, should further support the reliability of the soft tissue values used in reconstructions [23].

Repeatability was generally good. Reasons for lower repeatability could include a difference in interpretation of where the exact location of the landmarks is found, especially with the mid-philtrum and zygomaxillare, or may be due to the difficulty and difference in estimating the landmarks where it is not an exact point, such as the glabella (not a prominent point in females), and the frontal eminence. This could also have been the reason for the lower repeatability values for the lateral supra-labiale, gonion and supraglenoid landmarks. However, since these differences are not more than $1.5 \mathrm{~mm}$ at any of the landmarks, the difference that it will make on the appearance of a reconstruction is not expected to be much.

In general, there is little correlation between the variables that were difficult to repeat between the original observer (intraobserver) and the second observer (inter-observer). This may possibly be explained by small differences in how the observer(s) uses the measurement device, the fact that the sample measured by the two observers was not exactly the same, and it is also possible that a few more ambiguous cases were included in the sample of the original observer.

In conclusion, this study produced STT values for South African black females, using a large sample of 154 individuals. These values should be used in future reconstructions of South African black females. Future studies should be conducted in order to assess the validity of our assumptions that the use of population specific STT data increases the likelihood of recognition from reconstructed faces.

\section{Acknowledgements}

The authors would like to thank Prof. Z. Lockhat and Prof. J.L. Höll for permission to use CT scans, as well as Ms. Erika Smith and staff at the Department of Radiology of the Steve Biko Hospital for their advice and help with the CT scan programme. We are also indebted to Prof. P.J. Becker for providing assistance with the statistical analysis. Funding for this research was provided by the NRF (through the grant of M. Steyn) and the Rescom of the Faculty of Health Sciences.

\section{References}

[1] V.M. Phillips, N.A. Smuts, Facial reconstruction: utilization of computerized tomography to measure facial tissue thickness in a mixed racial population, Forensic Sci. Int. 83 (1996) 51-59.

[2] K.D. Kim, A. Ruprecht, G. Wang, J.B. Lee, D.V. Dawson, M.W. Vannier, Accuracy of facial soft tissue thickness measurements in personal computer-based multiplanar reconstructed computed tomographic images, Forensic Sci. Int. 155 (2005) 28-34.

[3] J.S. Rhine, H.R. Campbell, Thickness of facial tissues in American blacks, J. Forensic Sci. 25 (4) (1980) 847-858.

[4] W.A. Aulsebrook, Y.M. İşcan, J.H. Slabbert, P.J. Becker, Superimposition and reconstruction in forensic facial identification: a survey, Forensic Sci. Int. 75 (1995) 101-120.

[5] C. Wilkinson, Forensic Facial Reconstruction, Cambridge University Press, 2004

[6] D. Vandermeulen, P. Claes, D. Loeckx, S. De Greef, G. Willems, P. Suetens, Computerized craniofacial reconstruction using CT-derived implicit surface representations, Forensic Sci. Int. 159S (2006) S164-S174.

[7] M. Domaracki, C.N. Stephan, Facial soft tissue thicknesses in Australian adult cadavers, J. Forensic Sci. 51 (1) (2006) 5-10.

[8] S. De Greef, P. Claes, D. Vandermeulen, W. Mollemans, P. Suetens, G. Willems, Large-scale in-vivo Caucasian facial soft tissue thickness database for craniofacial reconstruction, Forensic Sci. Int. 159S (2006) S126-S146.

[9] S. Codinha, Facial soft tissue thickness for the Portuguese adult population, Forensic Sci. Int. 184 (80) (2009) 1-7.

[10] J.M. Starbuck, R.E. Ward, The affect of tissue depth variation on craniofacial reconstruction, Forensic Sci. Int. 172 (2007) 130-136.

[11] M.H. Manhein, G.A. Listi, R.E. Barsley, R. Musselman, N.E. Barrow, D.H. Ubelaker, In vivo facial tissue depth measurements for children and adults, J. Forensic Sci. 45 (2000) 48-60

[12] W.A. Aulsebrook, P.J. Becker, Y.M. İşcan, Facial soft-tissue thicknesses in the adult male Zulu, Forensic Sci. Int. 79 (1996) 83-102.

[13] S. dos S. Rocha, D.L. de P. Ramos, M. de G.P. Cavalcanti, Applicability of 3D-CT facial reconstruction for forensic individual identification, Pesqui. Odontol. Bras. 17 (1) (2003) 24-28

[14] D. Sahni, G. Sanjeev, I. Singh, J.P. Singh, Facial soft tissue thickness in northwest Indian adults, Forensic Sci. Int. 176 (2008) 137-146.

[15] J. Kollman, W. Buchly, Die Persistenz der Rassen und die Reconstruction der Physiognamie Prahistorisher Schadel, Arch. fur Anthropol. 22 (1898) 329-359.

[16] T. Suzuki, On the thickness of the soft parts of the Japanese face, J. Anthropol. Soc. Nippon 60 (1948) 7-11.

[17] J.C. Allan, Learning About Statistics, Macmillian South Africa (Publishers) Pty. Ltd., 1982.

[18] L. Ferrante, R. Cameriere, Statistical methods to assess the reliability of measurements in the procedures for forensic age estimation, Int. J. Legal Med. 123 (2009) 277-283.

[19] K.T. Taylor, Forensic Art and Illustration, CRC Press, 2001.

[20] C.N. Stephan, R.M. Norris, M. Henneberg, Does sexual dimorphism in facial soft tissue depths justify sex distinction in craniofacial identification? J. Forensic Sci. 50 (3) (2005) 513-518.

[21] C.N. Stephan, E.K. Simpson, Facial soft tissue depths in craniofacial identification (part I): an analytical review of the published adult data, J. Forensic Sci. 53 (6) (2008) 1257-1271.

[22] K.J. Reichs, E. Craig, Facial approximation: procedures and pitfalls, in: K.J. Reichs (Ed.), Forensic Osteology: Advances in the Identification of Human Remains, 2nd ed., Charles C. Thomas Publisher, Ltd., Springfield, IL, 1998, pp. 491-511.

[23] T.A. Rathbun, Personal identification facial reproductions, in: T.A. Rathbun, J.E. Buikstra (Eds.), Human Identification: Case Studies in Forensic Anthropology, Charles C. Thomas Publisher, Ltd., Springfield, IL, 1984, pp. 347-356. 